\title{
Effect of Certain Plasma Hormones, Metabolites, Milk $\alpha$-lactalbumin and Lactoferrin on the Persistency of Lactation in Sahiwal Cattle
}

\author{
S. M. Mishra ${ }^{1}$, A. K. Roy ${ }^{1}$, Singh Mahendra ${ }^{1}$ and I. D. Gupta ${ }^{2}$ \\ ${ }^{1}$ Animal Physiology Division, ${ }^{2}$ Animal Genetics \& Breeding Division, ICAR-National Dairy \\ Research Institute, Karnal-132001, India \\ *Corresponding author
}

\section{A B S T R A C T}

\begin{tabular}{|l|}
\hline Ke y w o r d s \\
$\begin{array}{l}\text { Hormones, } \\
\text { Metabolites, Milk } \\
\alpha \text {-LA and } \\
\text { lactoferrin, } \\
\text { Persistency, } \\
\text { Sahiwal cattle }\end{array}$ \\
\hline Article Info \\
\hline $\begin{array}{l}\text { Accepted: } \\
\text { 20 July 2020 } \\
\text { Available Online: } \\
\text { 10 August } 2020\end{array}$ \\
\hline \hline
\end{tabular}

A study was conducted on twelve apparently healthy Sahiwal cows selected from National Dairy Research institute's livestock herd. The cows were divided into two groups i.e. persistent and truncated based on their records of milking. The blood and milk samples were collected on 15, 30, 45, 60, 75, 90, 105, 120 days postpartum. Plasma glucose concentration was higher $(\mathrm{P}<0.05)$ in truncated than persistent cows on $60^{\text {th }}$ and $120^{\text {th }}$ days postpartum as well as between the days within same group. Plasma NEFA concentration was significantly higher $(\mathrm{P}<0.05)$ in truncated than persistent cows as well as between the days. Plasma cortisol was significantly higher $(\mathrm{P}<0.05)$ in truncated than Persistent cows. Plasma cortisol also varied $(\mathrm{P}<0.05)$ between the periods. Plasma GH was higher $(\mathrm{P}<0.05)$ in persistent than truncated cows but did not vary between periods. Plasma Oxytocin concentration did not vary significantly between animals as well as periods. Milk $\alpha$-LA was higher $(\mathrm{P}<0.05)$ in persistent than truncated cows. Milk $\alpha$-LA did not vary significantly between periods. Milk lactoferrin was higher $(\mathrm{P}<0.05)$ in persistent than truncated cows and also varied significantly between periods $(\mathrm{P}<0.05)$. It is concluded that the hormones such as GH andcortisol may have an effect on the persistency of lactation. Plasma metabolites like glucose, NEFA and milk proteins such as $\alpha$-LA and lactoferrin could also be associated with the persistency of lactation which is not merely a function of livestock management.

\section{Introduction}

India has achieved the top-most position in milk production mainly due to the largest number of bovines. The estimated milk production in the country is $187.7 \mathrm{MT}$ (Anonymous. 2019). However, milk production per animal per day is very low especially in our local cattle breeds. It is estimated that $80 \%$ of our cattle population is non-descript. The Sahiwal breed is utilized widely for the improvement of local stock or for initial crossbreeding of indigenous stock with European breeds in many hot-humid countries of the world because of its wellknown resistance to tropical diseases, endurance to hot climate of tropics, low cost of maintenance and higher percentage of milk constituents. The term persistency of lactation is used to refer to the degree with which the 
rate of milk secretion is maintained as lactation advances. The persistency of lactation is strongly influenced by the rate of apoptosis in the lactating glands (Gaines, 1987). Mammary apoptosis has been detected during lactation, in mammary tissue of lactating mice, goats and cattle (Stefanon et al., 2002). During lactation only $0.3 \%$ of mammary cells proliferate in a $24-\mathrm{h}$ period (Capuco et al., 2003). Yet this proliferative rate is sufficient to replace most mammary epithelial cells by the end of lactation. The pattern of the lactation curve is influenced by the number of secretory cells in the mammary gland and the synthetic activity of each secretory cell. Growth and differentiation of the glandular epithelium during puberty and pregnancy are important determinants of the total area of secretory epithelium and consequently of milk yield (Robinson et al., 1995). As lactation progresses the secretory cells gradually regress from a state of active synthesis and secretion to a non-secretory state through a process called "involution". The gradual involution starts around peak lactation and continues up to the time when the animals are dried off (Cannas et al., 2002). Maintenance of milk synthesis and secretion persistency is controlled by both systemic and local regulatory factors.

\section{Effect of plasma hormones on persistency of lactation}

The systemic factors involve hormones such as prolactin and growth hormone $(\mathrm{GH})$. As lactation progresses the level of growth hormone and prolactin decrease causing a reduction of milk synthesis (Barber et al., 1992). The influence of these hormones in reducing involution is mediated by the insulin-like growth factor-1, a hormone that is known to increase milk yield (Flint et al., 2000). Plasmin is the predominant protease in milk. In ruminants the effects of high doses of glucocorticoid are inhibitory but the effects of lower doses are ambiguous (Sjaastad et al., 2010). Cortisol is the main glucocorticoid in cattle and it is indicative of chronic stress in animals (Mostl \& Palme, 2002). The reduction in milk production due to dehydration stress or glucocorticoid was correlated with the activities of plasmin and channel blocking activity in the milk of the cows (Silanikove et al., 2000). Growth hormone $(\mathrm{GH})$, plays a key role in the control of postpartum development and growth in mammals (Butler and Le Roith, 2001). GH has an important role in maintaining the lactation. As lactation progresses the levels of $\mathrm{GH}$ decrease causing a reduction of milk synthesis (Akers, 2002). The influence of GH in reducing involution is mediated by the insulin-like growth factor-1 (Tonner et al., 2000), a hormone which increases milk yield. The GH whose receptors are not present in the mammary gland exerts its positive effects on milk yield indirectly by stimulating IGF-I synthesis. The gluconeogenesis is highly prioritized by the cow and is under hormonal regulation mainly by insulin, glucagon and growth hormone (Aschenbach et al., 2010). $\mathrm{GH}$ plays important role in this process, inhibiting lipid storage and increasing blood flow to the mammary gland (McMahon et al., 2001). Oxytocin influenced both the protein secretion process and the transfer of fat globules on the apical part of the epithelial cells. Prolactin is released at milking along with adrenocorticotrophic hormone (ACTH) and oxytocin (Gorewit, 1988). Oxytocin does not increase milk production, but it will stimulate contraction leading to milk ejection (Papich, 2015).

\section{Effect of Blood metabolites and milk proteins on persistency of lactation}

Mammary gland requires approximately $80 \%$ of the glucose supply to support the high milk production (Drackley et al., 2001). Glucose uptake by the mammary gland is essential for 
milk lactose synthesis (Rigout et al., 2003; Lemosquetet al., 2004). Glucose concentration sharply increases by 1 day prior to calving reflecting hormonal change that promotes gluconeogenesis and glycogenolysis (Knight et al., 2004). Blood NEFA concentrations are strong indicator of disease, reproductive performance and milk production than blood BHBA concentration (Huzzey et al., 2011). Cows in severe negative energy balance have a higher concentration of NEFA and a plasma concentration of $>600 \mu \mathrm{mol} / \mathrm{L}$ indicates severe negative energy balance. The NEFA are utilized for about $40 \%$ of milk fat during the first days of lactation (Adewuyi, 2005). Lactose synthetaseis composed of galactosyltransferase and the milk protein $\alpha$ Lactalbumin (Gradinaru, 2015). Folding variants of $\alpha$-lactalbumin ( $\alpha$-LA) are known to induce cell death in a number of cell types, including mammary epithelial cells (MEC). Bovine $\alpha$-LA has an important role in involution and/or maintaining the luminal space in mammary alveoli during lactation. It could be possible to enhance milk protein expression and/or improve lactation persistency by influencing the balance between proliferation and apoptosis of BMEC (Riley et al., 2008). Presence of $\alpha$-LA is indicator of responsiveness of mammary gland to the lactogenic hormonal complex (Husveth, 2011). Prolactin induces the secretion of $\alpha$-lactalbumin, which helps in maintaining persistency of lactation. Lactoferrin has a variety of functions viz. antibacterial, antiviral, antifungal, antiparasitic, anti-inflammatory, anticarcinogenic and antitumor activities (Tomita et al., 2009). Lactoferrin may also serve as a modulator of immune and inflammatory responses. Although bovine colostrum contains up to $5 \mathrm{mg} / \mathrm{ml}$ lactoferrin, levels drop very rapidly as lactation proceeds, so that mature bovine milk normally contains only $20-200 \mu \mathrm{g} / \mathrm{ml}$ lactoferrin. The direct effect of LTF on persistency of lactation is not yet identified but its effect on cell differentiation, proliferation and its cytokine like activities with respect to immunoepithelial cells are well documented.

\section{Materials and Methods}

The geographical location of NDRI livestock farm is at an altitude of 250 meters above the mean sea level (MSL) in the Indo-gangetic alluvial plains on 29042' $\mathrm{N}$ latitude and 72002' E longitude. The climate of the farm is subtropical in nature. The minimum temperature falls to $20 \mathrm{C}$ in winter months, whereas the maximum temperature goes up to $450 \mathrm{C}$ in summer. The annual rainfall is about 760 to $960 \mathrm{~mm}$ out of which most of the rainfall is received during the months of July and August. The relative humidity ranges from 41 to $85 \%$. The experiment was performed in compliance with the regulations of the Institutional Animal Ethics Committee under the approved research program. Sahiwal cows $(n=12)$ at 15 days postpartum were selected from the herd of National Dairy Research Institute, Karnal and divided into 2 groups of 6 animals each. Six cows were kept as control on the basis of excellent persistency of their milk yield and six test animals chosen showing truncation in their milk production or prior history of truncation after attending peak milk yield. The plasma samples were collected at fortnightly intervals starting 15 days after parturition i.e. on $15,30,45,60$, 75, 90, and 105 days from all cows for analysis of blood metabolites (Glucose, NEFA) and hormones (Cortisol, GH, Oxytocin). Milk samples were also collected fortnightly starting 15 days postpartum i.e. on $15,30,45,60,75,90$, and 105 days from all cows for the estimation of whey proteins $(\alpha-$ LA and Lactoferrin). Blood samples were drawn in sterile heparinized tubes from jugular vein puncture posing minimum disturbances at 15 days interval during 
experimental period. Blood $(8 \mathrm{ml})$ was collected on days $15,30,45,60,75,90,105$ with respect to the day of parturition from each animal. Samples were brought to the laboratory in chilled ice boxes after collection and centrifuged at $1200^{*} \mathrm{~g}$ at $4^{\circ} \mathrm{C}$ for 20 minutes to separate plasma which was stored at $-20^{\circ} \mathrm{C}$ until analyzed. Milk samples were collected once in a day during evening (6.00 pm). The milk fat was separated by centrifugation at $5^{\circ} \mathrm{C}$ at 3800 R.P.M. for 20 minutes. The skimmed milk was stored at $20^{\circ} \mathrm{C}$ for whey protein estimation. Milk $\alpha$ Lactalbumin, lactoferrin and NEFAwere determined by ELISA kitsfrom SunRed Biotechnological Company whereas Glucose was estimated in plasma samples by GODPAP TRINDER's kit from Recombigen Pvt. Ltd., China. Oxytocin, GH and Cortisol was determined in blood plasma by ELISA kitsfrom Bioassay Technology Laboratory, China.

\section{Results and Discussion}

\section{Plasma glucose}

Glucose is used by mammary gland cells to form lactose (Mcmanaman\& Neville, 2003). The blood glucose concentration during different periods varied from $63.85 \pm 5.7$ to $77.02 \pm 3.45 \mathrm{mg} / \mathrm{dl}$ and $57.92 \pm 4.39$ to $76.65 \pm 5.14 \mathrm{mg} / \mathrm{dl}$ in persistent and truncated cows respectively (Table-1). The result shows significant difference $(\mathrm{P}<0.05)$ between persistent and truncated cows in glucose levels on $60^{\text {th }}$ day and $120^{\text {th }}$ day postpartum (Fig.-1). Mammary gland requires approximately $80 \%$ of the glucose supply to support the high milk production (Drackley et al., 2001). Glucose uptake by the mammary gland is essential for milk synthesis (Rigout et al., 2003; Lemosquet et al., 2004). Glucose concentration is sharply increased by 1 day prior to calving reflecting hormonal change that promotes gluconeogenesis and glycogenolysis (Knight et al., 2004). The significant difference of glucose may be due to less utilization of glucose by mammary gland to synthesize lactose. It could also be attributed to certain genetic factors. Insulin stimulates glucose uptake via phosphatidylinositide 3-kinase-linked signaling pathway in bovine mammary epithelial cells (Zhao et al., 2014).

\section{Plasma NEFA}

The plasma NEFA concentration during different periods varied from $223.20 \pm 9.51$ to $401.14 \pm 8.13 \mu \mathrm{M} / \mathrm{L}$ and $265.67 \pm 5.04$ to $427.33 \pm 8.90 \mu \mathrm{M} / \mathrm{L}$ in persistent and truncated cows respectively (Table-1). The result shows significant difference $(\mathrm{P}<0.05)$ between persistent and truncated cows in NEFA levels on $15^{\text {th }}, 30^{\text {th }}, 45^{\text {th }}, 60^{\text {th }}, 75^{\text {th }}, 90^{\text {th }}$ and $105^{\text {th }}$ day postpartum (Fig.-2). It shows the negative energy balance in truncated Sahiwal cows as the level of NEFA are elevated in comparison to the persistent Sahiwal cows on the same days. The significant higher levels of NEFA in truncated Sahiwal cows indicate effective mobilization of adipose tissue in truncated lactation group (Drackley, 1999). Cows in negative energy balance mobilize more body fat and produce glycerol for energy which leads to increased NEFA concentrations in blood (DeVries and Veerkamp, 2000). Plasma NEFA is an important attribute to help evaluate energy balance of the cow because they are elevated in energetic stress (Burke and Roche, 2007) and stored fat is mobilized (Holcomb et al., 2001).

\section{Plasma cortisol}

The plasma cortisol concentration during different periods varied from $2.42 \pm 0.08$ to $6.32 \pm 0.18 \mathrm{ng} / \mathrm{mL}$ and $2.83 \pm 0.15$ to $7.02 \pm$ $0.12 \mathrm{ng} / \mathrm{mL}$ in persistent and truncated cows respectively (Table-2). The result shows significant difference $(\mathrm{P}<0.05)$ between 
persistent and truncated cows in cortisol levels on $15^{\text {th }}, 30^{\text {th }}, 45^{\text {th }}, 60^{\text {th }}, 75^{\text {th }}$ and $105^{\text {th }}$ day postpartum (Fig.-3). Cortisol is indicative of chronic stress in animals (Mostl \& Palme, 2002). The stress is often linked with plasminogen-plasmin system (PPS) which is an enzymatic mechanism in milk, leading to the breakdown of the major milk protein casein.

The reduction in milk production due to dehydration stress or glucocorticoid was correlated with the activities of plasmin and channel blocking activity in the milk of the cows (Silanikove et al., 2000). Some workers indicate that a change in mammary cell number is due to stress imposed imbalance between cell proliferation and cell removal and a principal cause of declining milk production (Stefanon et al., 2002).

Cortisol has got a major function in enhancing the action of PRL in stimulating differentiation of the epithelium and milk protein gene expression in the mammary gland during lactogenesis (Akers, 2002).

\section{Plasma GH}

The plasma GH concentration during different periods varied from $1.84 \pm 0.06$ to $2.18 \pm 0.06$ $\mathrm{ng} / \mathrm{mL}$ and $1.58 \pm 0.10$ to $2.11 \pm 0.06 \mathrm{ng} / \mathrm{mL}$ in persistent and truncated cows respectively (Table 2). The result shows significant difference $(\mathrm{P}<0.05)$ between persistent and truncated cows in GH levels on $30^{\text {th }}, 45^{\text {th }}, 60^{\text {th }}$ and $90^{\text {th }}$ day postpartum (Fig.-4). The significant role of $\mathrm{GH}$ on persistency of lactation in Sahiwal cows may be due to lactopoietic effect of GH through IGF-1 (Purup et al., 1993) which acts directly on the mammary gland. GH was associated with an increase in mammary cell proliferation in cows (Capuco et al., 2001) Although the action of GH is mediated mainly through the IGF axis, there is evidence that GH may also act without IGF-I to stimulate milk production (Hadsell et al., 2008). The influence of $\mathrm{GH}$ in reducing involution is mediated by the insulin-like growth factor-I (Tonner et al., 2000). The GH whose receptors are not present in the mammary gland exerts its positive effects on milk yield indirectly by stimulating IGF-I synthesis.

Table.1 Mean values of plasma metabolites in Persistent and Truncated cows

\begin{tabular}{|c|c|c|c|c|c|c|c|c|}
\hline \multirow[t]{3}{*}{ Group } & \multicolumn{8}{|c|}{ Glucose (mg/dl) } \\
\hline & \multicolumn{8}{|c|}{ Postpartum } \\
\hline & 15 & 30 & 45 & 60 & 75 & 90 & 105 & 120 \\
\hline Persistent & $\begin{array}{l}70.45^{\mathrm{ab}} \\
\pm 4.45\end{array}$ & $\begin{array}{l}77.02^{\mathrm{b}} \\
\pm 3.45\end{array}$ & $\begin{array}{l}68.17^{\mathrm{a}} \\
\pm 4.09\end{array}$ & $\begin{array}{c}64.52^{\mathrm{aX}} \\
\pm 3.07\end{array}$ & $\begin{array}{c}63.85^{\mathrm{a}} \\
\pm 5.7\end{array}$ & $\begin{array}{c}71.41^{\mathrm{ab}} \\
\pm 3.02\end{array}$ & $\begin{array}{l}75.43^{\mathrm{b}} \\
\pm 2.22\end{array}$ & $\begin{array}{l}75.26^{\mathrm{b}} \\
\pm 1.86\end{array}$ \\
\hline Truncated & $\begin{array}{l}67.46^{\mathrm{b}} \\
\pm 1.49\end{array}$ & $\begin{array}{c}70.17^{\mathrm{bc}} \\
\pm 3.69\end{array}$ & $\begin{array}{l}70.18^{\mathrm{bc}} \\
\pm 1.03\end{array}$ & $\begin{array}{c}73.09^{\mathrm{bcY}} \\
\pm 4.43\end{array}$ & $\begin{array}{l}57.92^{\mathrm{a}} \\
\pm 4.39\end{array}$ & $\begin{array}{c}71.95^{\mathrm{bc}} \\
\pm 3.49\end{array}$ & $\begin{array}{l}76.65^{\mathrm{b}} \\
\pm 5.14\end{array}$ & $\begin{array}{l}74.32^{\mathrm{c}} \\
\pm 1.75\end{array}$ \\
\hline \multicolumn{9}{|c|}{ NEFA $(\mu \mathrm{mol} / \mathrm{L})$} \\
\hline Persistent & $\begin{array}{c}401.14^{\mathrm{eX}} \\
\pm 8.13\end{array}$ & $\begin{array}{r}321.28^{\mathrm{d}} \\
\pm 6.30\end{array}$ & $\begin{array}{r}286.3 \\
\pm 6.3\end{array}$ & \begin{tabular}{l|r}
$c x$ & 264 \\
5 & \pm 6
\end{tabular} & & $\begin{array}{c}255.5^{\mathrm{bX}} \\
\pm 9.98\end{array}$ & $\begin{array}{c}239.12^{\mathrm{aX}} \\
\pm 4.29\end{array}$ & $\begin{array}{c}223.20^{\mathrm{ax}} \\
\pm 9.51\end{array}$ \\
\hline Truncated & $\begin{array}{c}427.33^{\mathrm{tY}} \\
\pm 8.90\end{array}$ & $\begin{array}{r}348.83^{\mathrm{e}} \\
\pm 6.18\end{array}$ & $\begin{array}{r}318.3 \\
\pm 6.6\end{array}$ & $\begin{array}{r}301 \\
\pm 9\end{array}$ & & $\begin{array}{c}290.17^{\mathrm{bcY}} \\
\pm 6.03\end{array}$ & $\begin{array}{c}280.18^{\mathrm{bY}} \\
\pm 6.03\end{array}$ & $\begin{array}{c}265.67^{\mathrm{aY}} \\
\pm 5.04\end{array}$ \\
\hline
\end{tabular}


Table.2 Mean values of plasma hormones in persistent and truncated cows

\begin{tabular}{|c|c|c|c|c|c|c|c|}
\hline \multirow[t]{3}{*}{ Group } & \multicolumn{7}{|c|}{ Cortisol (ng/ml) } \\
\hline & \multicolumn{7}{|c|}{ Postpartum } \\
\hline & 15 & 30 & 45 & 60 & 75 & 90 & 105 \\
\hline Persistent & $\begin{array}{l}6.32^{\mathrm{fX}} \\
\pm 0.18\end{array}$ & $\begin{array}{l}5.86^{\mathrm{eX}} \\
\pm 0.12\end{array}$ & $\begin{array}{l}5.14^{\mathrm{dX}} \\
\pm 0.14\end{array}$ & $\begin{array}{l}4.21^{\mathrm{cX}} \\
\pm 0.11\end{array}$ & $\begin{array}{l}3.76^{\mathrm{bX}} \\
\pm 0.31\end{array}$ & $\begin{array}{c}2.86^{\mathrm{a}} \\
\pm 0.10\end{array}$ & $\begin{array}{l}2.42^{\mathrm{aX}} \\
\pm 0.08\end{array}$ \\
\hline Truncated & $\begin{array}{l}7.02^{\mathrm{fY}} \\
\pm 0.12\end{array}$ & $\begin{array}{l}6.65^{\mathrm{eY}} \\
\pm 0.18\end{array}$ & $\begin{array}{l}6.09^{\mathrm{dY}} \\
\pm 0.23\end{array}$ & $\begin{array}{l}4.96^{\mathrm{cY}} \\
\pm 0.09\end{array}$ & $\begin{array}{l}4.46^{\mathrm{bY}} \\
\pm 0.09\end{array}$ & $\begin{array}{r}3.18^{\mathrm{a}} \\
\pm 0.17\end{array}$ & $\begin{array}{l}2.83^{\mathrm{aY}} \\
\pm 0.15\end{array}$ \\
\hline \multicolumn{8}{|c|}{ Growth Hormone (ng/ml) } \\
\hline Persistent & $\begin{array}{r}1.92^{\mathrm{a}} \\
\pm 0.09\end{array}$ & $\begin{array}{l}1.89^{\mathrm{aX}} \\
\pm 0.09\end{array}$ & $\begin{array}{l}1.84^{\mathrm{aX}} \\
\pm 0.06\end{array}$ & $\begin{array}{l}1.88^{\mathrm{aX}} \\
\pm 0.03\end{array}$ & $\begin{array}{c}1.99^{\mathrm{a}} \\
\pm 0.07\end{array}$ & $\begin{array}{l}2.10^{\mathrm{bX}} \\
\pm 0.01\end{array}$ & $\begin{array}{l}2.18^{\mathrm{b}} \\
\pm 0.06\end{array}$ \\
\hline Truncated & $\begin{array}{r}1.78^{\mathrm{b}} \\
\pm 0.06\end{array}$ & $\begin{array}{c}1.66^{\mathrm{abY}} \\
\pm 0.09\end{array}$ & $\begin{array}{l}1.58^{\mathrm{aY}} \\
\pm 0.10\end{array}$ & $\begin{array}{l}1.79^{\mathrm{bY}} \\
\pm 0.04\end{array}$ & $\begin{array}{l}1.87^{\mathrm{bc}} \\
\pm 0.05\end{array}$ & $\begin{array}{l}2.02^{\mathrm{cd} Y} \\
\pm 0.04\end{array}$ & $\begin{array}{l}2.11^{\mathrm{d}} \\
\pm 0.06\end{array}$ \\
\hline \multicolumn{8}{|c|}{ Oxytocin (pmol/L) } \\
\hline Persistent & $\begin{array}{l}17.06 \\
\pm 4.24\end{array}$ & $\begin{array}{l}17.01 \\
\pm 4.22\end{array}$ & $\begin{array}{l}18.31 \\
\pm 4.09\end{array}$ & $\begin{array}{r}16.05 \\
\pm 4.97\end{array}$ & $\begin{array}{l}17.41 \\
\pm 3.74\end{array}$ & $\begin{array}{l}16.07 \\
\pm 3.60\end{array}$ & $\begin{array}{r}15.57 \\
\pm 4.78\end{array}$ \\
\hline Truncated & $\begin{array}{l}17.21 \\
\pm 4.27\end{array}$ & $\begin{array}{r}19.79 \\
\pm 4.84\end{array}$ & $\begin{array}{l}17.59 \\
\pm 4.10\end{array}$ & $\begin{array}{r}18.90 \\
\pm 4.90\end{array}$ & $\begin{array}{l}20.17 \\
\pm 4.58\end{array}$ & $\begin{array}{l}16.88 \\
\pm 4.20\end{array}$ & $\begin{array}{r}15.93 \\
\pm 4.86\end{array}$ \\
\hline
\end{tabular}

Values with different superscript ${ }^{\mathrm{a}, \mathrm{b}, \mathrm{c}, \mathrm{d}, \mathrm{e}, \mathrm{f}}$ and ${ }^{\mathrm{X}, \mathrm{Y}}$ in a row and column differ significantly $(\mathrm{P}<0.05)$

Table. 3 Mean values of milk proteins in persistent and truncated cows

\begin{tabular}{|c|c|c|c|c|c|c|c|c|}
\hline \multirow[t]{3}{*}{ Group } & \multicolumn{8}{|c|}{$\alpha$-Lactalbumin $(\mu \mathrm{g} / \mathrm{dl})$} \\
\hline & \multicolumn{8}{|c|}{ Postpartum } \\
\hline & 15 & 30 & 45 & 60 & 75 & 90 & 105 & 120 \\
\hline Persistent & $\begin{array}{c}1.48^{\mathrm{cX}} \\
\pm 0.007\end{array}$ & $\begin{array}{l}1.43^{\mathrm{cX}} \\
\pm 0.01\end{array}$ & $\begin{array}{l}1.37^{b X} \\
\pm 0.03\end{array}$ & $\begin{array}{l}1.34^{\mathrm{bX}} \\
\pm 0.01\end{array}$ & $\begin{array}{l}1.28^{\mathrm{aX}} \\
\pm 0.02\end{array}$ & $\begin{array}{l}1.24^{\mathrm{aX}} \\
\pm 0.01\end{array}$ & $\begin{array}{l}1.22^{\mathrm{aX}} \\
\pm 0.01\end{array}$ & $\begin{array}{c}1.21^{\mathrm{aX}} \\
\pm 0.006\end{array}$ \\
\hline Truncated & $\begin{array}{l}0.96^{\mathrm{Y}} \\
\pm 0.06\end{array}$ & $\begin{array}{l}0.91^{\mathrm{Y}} \\
\pm 0.05\end{array}$ & $\begin{array}{l}0.86^{\mathrm{Y}} \\
\pm 0.03\end{array}$ & $\begin{array}{c}0.88^{\mathrm{Y}} \\
\pm 0.008\end{array}$ & $\begin{array}{l}0.86^{\mathrm{Y}} \\
\pm 0.01\end{array}$ & $\begin{array}{l}0.82^{\mathrm{Y}} \\
\pm 0.02\end{array}$ & $\begin{array}{l}0.82^{\mathrm{Y}} \\
\pm 0.02\end{array}$ & $\begin{array}{l}0.88^{Y} \\
\pm 0.02\end{array}$ \\
\hline \multicolumn{9}{|c|}{ Lactoferrin $(\mu \mathrm{g} / \mathrm{ml})$} \\
\hline Persistent & $\begin{array}{c}51^{\mathrm{cX}} \\
\pm 3\end{array}$ & $\begin{array}{c}47^{\mathrm{bcX}} \\
\pm 4\end{array}$ & $\begin{array}{c}44^{\mathrm{bX}} \\
\pm 3\end{array}$ & $\begin{array}{c}41^{\mathrm{abX}} \\
\pm 4\end{array}$ & $\begin{array}{c}36^{\mathrm{aX}} \\
\pm 4\end{array}$ & $\begin{array}{c}35^{\mathrm{aX}} \\
\pm 4\end{array}$ & $\begin{array}{c}37^{\mathrm{aX}} \\
\pm 4\end{array}$ & $\begin{array}{c}37^{\mathrm{aX}} \\
\pm 6\end{array}$ \\
\hline Truncated & $\begin{array}{c}37^{\mathrm{cY}} \\
\pm 1\end{array}$ & $\begin{array}{c}29^{\mathrm{bcY}} \\
\pm 1\end{array}$ & $\begin{array}{l}25^{\mathrm{bcY}} \\
\pm 0.8\end{array}$ & $\begin{array}{l}23^{\mathrm{bY}} \\
\pm 0.8\end{array}$ & $\begin{array}{c}19^{\mathrm{abY}} \\
\pm 5\end{array}$ & $\begin{array}{c}22^{\mathrm{bY}} \\
\pm 3\end{array}$ & $\begin{array}{c}21^{\mathrm{bY}} \\
\pm 3\end{array}$ & $\begin{array}{c}13^{\mathrm{aY}} \\
\pm 2\end{array}$ \\
\hline
\end{tabular}

Fig.1 Plasma glucose profile in experimental Sahiwal cows

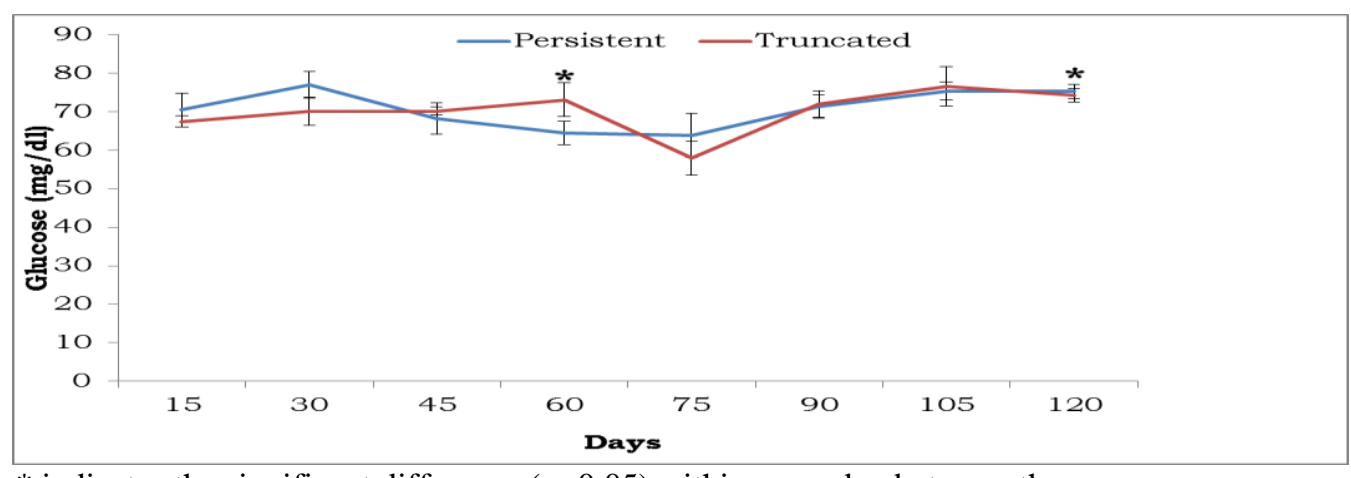

* indicates the significant difference $(\mathrm{p}<0.05)$ within same day between the groups 
Fig.2 Plasma NEFA profile in experimental Sahiwal cows

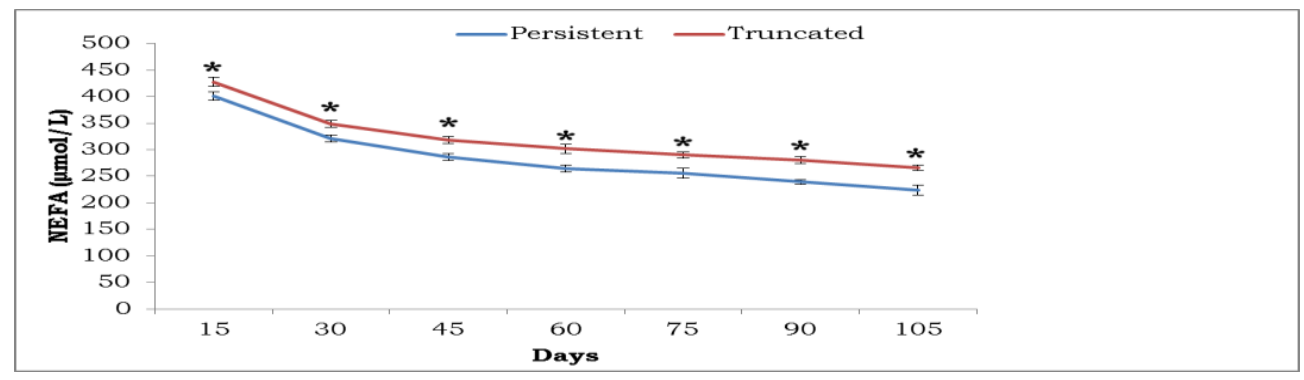

* indicates the significant difference $(\mathrm{p}<0.05)$ within same day between the groups

Fig.3 Plasma cortisol profile in experimental Sahiwal cows

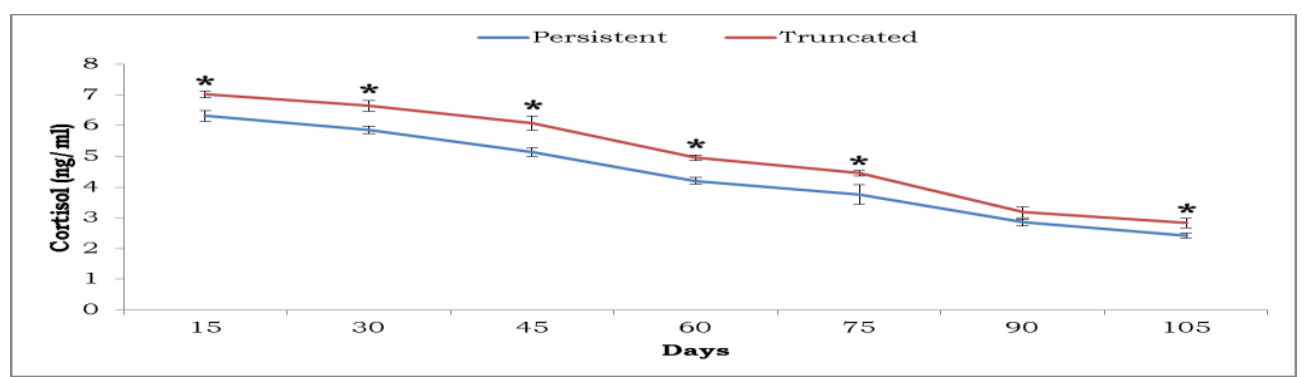

* indicates the significant difference $(\mathrm{p}<0.05)$ within same day between the groups

Fig.4 Plasma GH profile in Experimental Sahiwal Cows

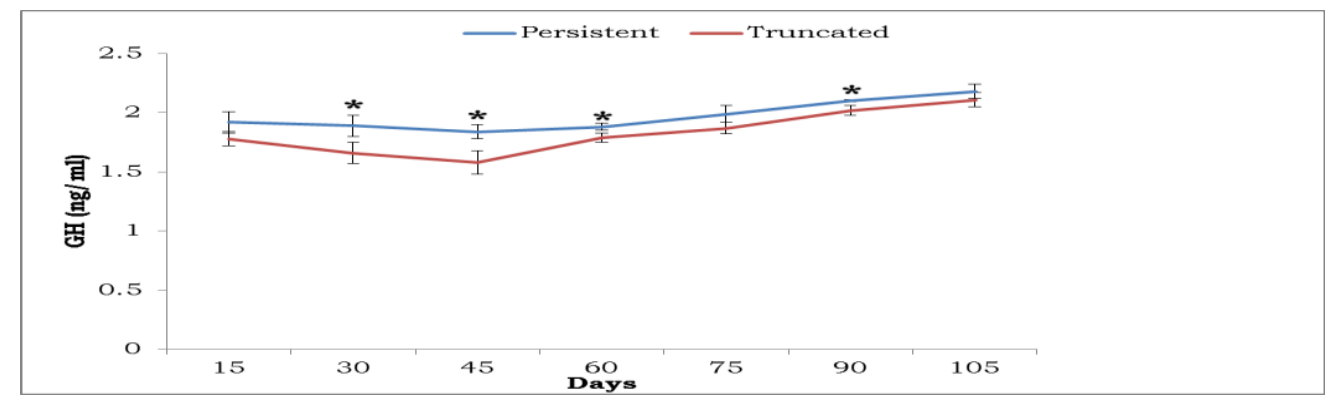

* indicates the significant difference $(\mathrm{p}<0.05)$ within same day between the groups

Fig.5 Plasma oxytocin profile in experimental Sahiwal cows

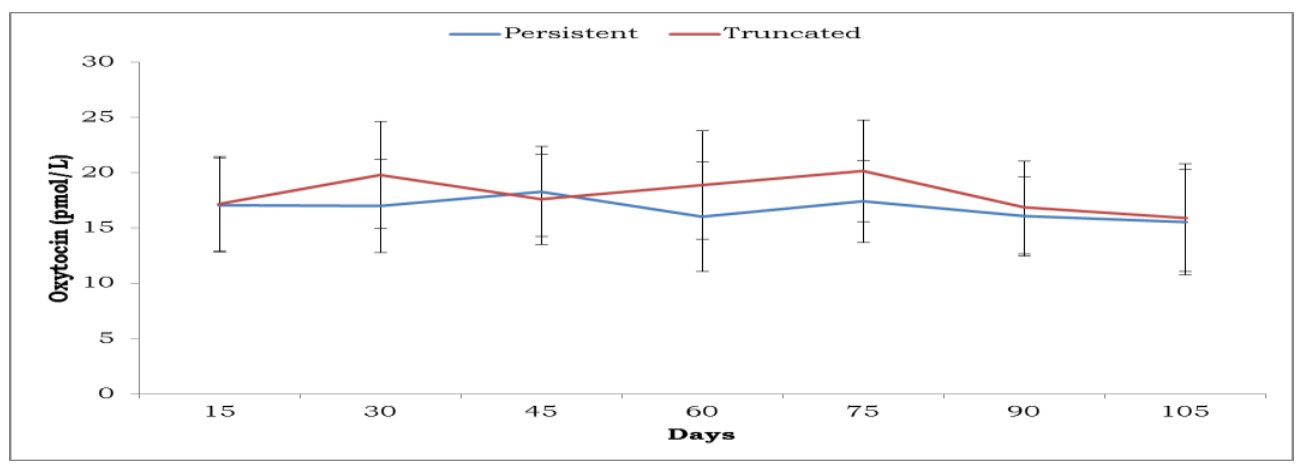


Fig.6 Milk $\alpha$-LA profile in experimental Sahiwal cows

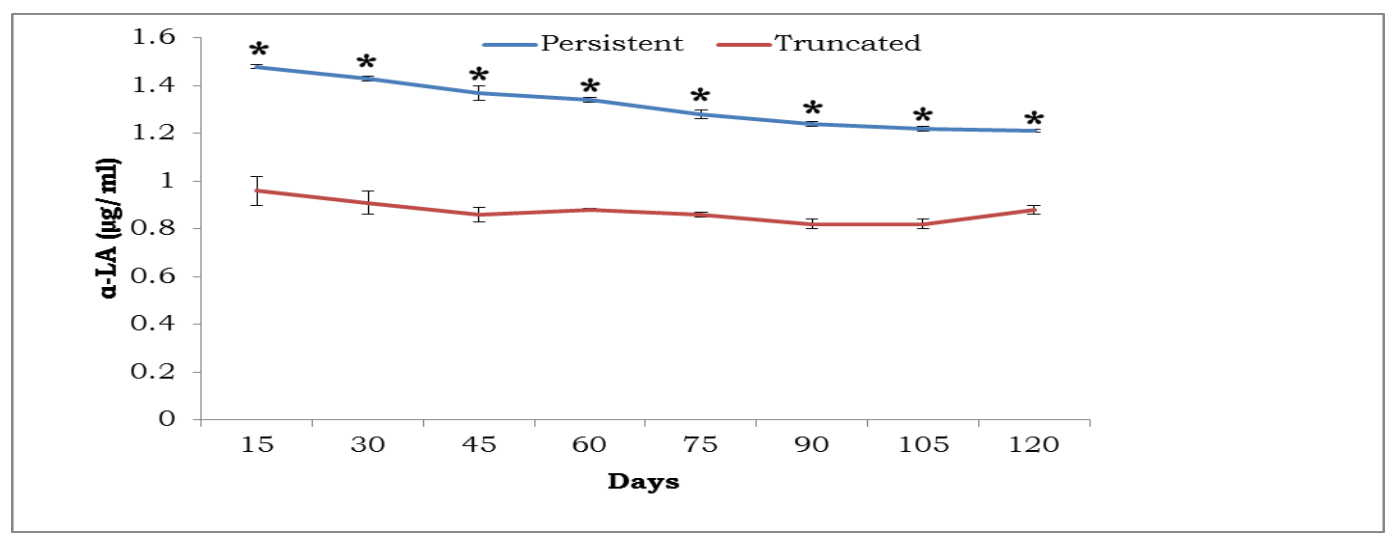

* indicates the significant difference $(\mathrm{p}<0.05)$ within same day between the groups

Fig.7 Milk LTF profile in Experimental Sahiwal Cows

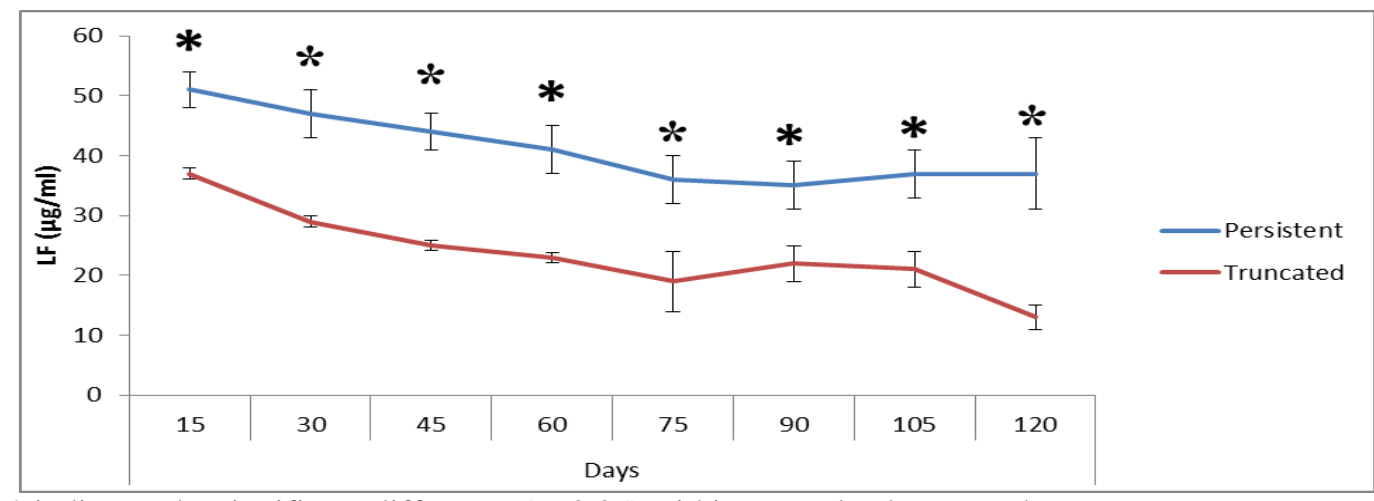

* indicates the significant difference $(\mathrm{p}<0.05)$ within same day between the groups

\section{Plasma Oxytocin}

The plasma oxytocin concentration during different periods varied from $15.57 \pm 4.78$ to $18.31 \pm 4.09 \mathrm{pM} / \mathrm{L}$ and $15.93 \pm 4.86$ to $20.17 \pm 4.58 \mathrm{pM} / \mathrm{L}$ in persistent and truncated cows respectively (Table-2). The result shows non-significant difference $(\mathrm{P}<0.05)$ between persistent and truncated cows in oxytocin levels (Fig.-5). Exogenous oxytocin was associated with increased milk production of both dairy cows and sheep (Lollivier \& Marnet, 2005 and Zamiri et al., 2001). Oxytocin might act on the mammary epithelial cells (Lollivier et al., 2002) to influence both the protein secretion process and the transfer of fat globules on the apical part of the epithelial cells. The present study shows no direct significant role on persistency of Sahiwal cows since its role is mainly prevalent as milk ejecting hormone which is in agreement with Papich, (2015). However, milk ejection is very important for regulating persistency of lactation in directly.

\section{$\alpha$-Lactalbumin}

The $\alpha$-LA concentration during different period varied from $1.21 \pm 0.006$ to $1.48 \pm$ $0.007 \mu \mathrm{g} / \mathrm{mL}$ and $0.82 \pm 0.02$ to $0.96 \pm 0.06$ $\mu \mathrm{g} / \mathrm{mL}$ in persistent and truncated cows respectively (Table-3). The result shows significant difference $(\mathrm{P}<0.05)$ between persistent and truncated cows in $\alpha$-LA levels on $15^{\text {th }}, 30^{\text {th }}, 45^{\text {th }}, 60^{\text {th }} 90^{\text {th, }} 105^{\text {th }}$ and $120^{\text {th }}$ day postpartum (Fig. 6). Presence of $\alpha$-LA is 
indicator of responsiveness of mammary gland to the lactogenic hormonal complex (Husveth, 2011) which is responsible for the differentiation of the mammary secretory epithellium. The development in lactogenesis of the rough as well as smooth endoplasmic reticulum, and the Golgi apparatus results in mammary synthesis of proteins, fat and lactose, respectively. $\alpha$-LA being the important whey protein is also dependent on prolactin. Prolactin directly stimulates the transcription of casein and other protein genes. Prolactin induces the secretion of $\alpha$ lactalbumin, an enzyme moiety of lactose synthase which helps in maintaining the persistency of lactation. $\alpha$-Lactalbuminin has been found to increase in response to addition of bovine prolactin (Akers and Denbow, 2008). $\alpha$-LA also has role in proper involution of mammary gland without which the new cell formation can't takes place properly. Bovine $\alpha$-LA reduced the viability of primary bovine mammary epithelial cells (BMEC) and induced caspase activity in mammospheres which leads to proper involution (Riley et al., 2008). Hence, less $\alpha$-LA in truncated cows may be due to decreased response of mammary gland to prolactin and reduced lactose synthase activity which leads to less lactose formation and seized milk production.

\section{Lactoferrin}

LTF concentration during different periods varied from $0.35 \pm 0.04$ to $0.51 \pm 0.03 \mu \mathrm{g} / \mathrm{mL}$ and $0.13 \pm 0.02$ to $0.37 \pm 0.11 \mu \mathrm{g} / \mathrm{mL}$ in persistent and truncated cows respectively (Table-3). The result shows significant difference $(\mathrm{P}<0.05)$ between persistent and truncated cows in LTF levels on $30^{\text {th }}, 45^{\text {th }}$, $60^{\text {th, }} 90^{\text {th }} 105^{\text {th }}$ and $120^{\text {th }}$ day postpartum (Fig.-7). Lactoferrin has antibacterial activity which is affected through the sequestration of iron necessary for microbial growth. Lactoferrin may also serve as a modulator of immune and inflammatory responses
(Legrand, 2005). Lactoferrin enhanced cell proliferation and the stimulatory effect of lactoferrin on proliferation depended on the degree of iron saturation (Bi et al., 1997). LTF is able to influence cutaneous immune and inflammatory processes secondary to regulation of the production of TNF- $\alpha$ and possibly other cytokines (Kimber et al., 2002). The significant difference shown in the level of LTF in milk of truncated Sahiwal cows may point towards the impaired prolactin mechanism. Prolactin is essential hormone when it comes to lactation. Hence, the less LTF in truncated cows may be due to less PRL stimulated LF synthesis in BMECs.

In conclusion the plasma NEFA and cortisol levels were significantly higher in the truncated while plasma $\mathrm{GH}$, milk $\alpha$ lactalbumin and lactoferrin were higher in the persistent cows. These findings could be utilized to address the problems of truncated lactation in Sahiwal cows.

\section{Acknowledgement}

The authors are grateful to Director, NDRI Karnal for providing necessary facilities to carry out the present research work.

\section{Data availability statement}

All the data of this study were represented in the figures and table. However, the raw data of ELISA results will be shared on request basis.

\section{Conflict of interest}

The authors declare no competing or financial interests.

\section{Animal Welfare Statement}

"The authors confirm that the ethical policies of the journal, as noted on the journal's author 
guidelines page, have been adhered to and the appropriate ethical review committee approval has been received. The authors confirm that they have followed EU standards for the protection of animals used for scientific purposes."

\section{References}

Adewuyi, A. A., Gruys, E., and Van Eerdenburg, F. J. C. M. (2005).Non esterified fatty acids (NEFA) in dairy cattle. A review. Veterinary quarterly, 27(3), 117-126.

Akers, R. M. 2002. Lactation and The Mammary Gland., United State.

Akers, R. M., and Denbow, M. D. (2008).Anatomy and physiology of domestic animals (No. 636.0892 A3A5).

Anonymous. 2019. Basic Animal Husbandry Statistics. Government of India, Ministry of Agriculture, Department of Animal Husbandry, Dairying and Fisheries, KrishiBhavan, New Delhi.

Aschenbach, J. R., Kristensen, N. B., Donkin, S. S., Hammon, H. M., and Penner, G. B. (2010). Gluconeogenesis in dairy cows: the secret of making sweet milk from sour dough. IUBMB life, 62(12), 869877.

Barber, M. C., Clegg, R. A., Finley, E., Vernon, R. G., and Flint, D. J. (1992). The role of growth hormone, prolactin and insulinlike growth factors in the regulation of rat mammary gland and adipose tissue metabolism during lactation. Journal of Endocrinology, 135(2), 195-202.

Bi, B. Y., Lefebvre, A. M., Duś, D. A. N. U. T. A., Spik, G., and Mazurier, J. 1997. Effect of lactoferrin on proliferation and differentiation of the Jurkat human lymphoblastic $\mathrm{T}$ cell line. Archivum immunologiae ettherapiae experimentalis, 45(4), 315-320.

Burke, C. R., and Roche, J. R. (2007).Effects of pasture feeding during the periparturient period on postpartum anovulation in grazed dairy cows. Journal of Dairy
Science, 90(9), 4304-4312.

Butler, A. A., and Roith, D. L. (2001). Control of growth by the somatropic axis: growth hormone and the insulin-like growth factors have related and independent roles. Annual review of physiology, 63(1), 141-164.

Cannas, A., Nudda, A., and Pulina, G. (2002).Nutritional strategies to improve lactation persistency in dairy ewes.

Capuco, A. V., Ellis, S. E., Hale, S. A., Long, E., Erdman, R. A., Zhao, X., and Paape, M. J. 2003. Lactation persistency: Insights from mammary cell proliferation studies. Journal of animal science., 81(15_suppl_3), 18-31.

Capuco, A. V., Wood, D. L., Baldwin, R., Mcleod, K., and Paape, M. J. (2001). Mammary cell number, proliferation, and apoptosis during a bovine lactation: relation to milk production and effect of bST. Journal of dairy science, 84(10), 2177-2187.

De Vries, M. J., and Veerkamp, R. F. (2000).Energy balance of dairy cattle in relation to milk production variables and fertility.Journal of dairy science, 83(1), 62-69.

Drackley, J. K. (1999). Biology of dairy cows during the transition period: The final frontier?.Journal of dairy science, 82(11), 2259-2273.

Drackley, J. K., Overton, T. R., and Douglas, G. N. (2001).Adaptations of glucose and long-chain fatty acid metabolism in liver of dairy cows during the periparturient period. Journal of Dairy Science, 84, E100-E112.

Flint, D. J., Tonner, E., and Allan, G. J. (2000). Insulin-like growth factor binding proteins: IGF-dependent and-independent effects in the mammary gland. Journal of mammary gland biology and neoplasia, 5(1), 65-73.

Gaines, W. L. 1927. Persistency of lactation in dairy cows: a preliminary study of certain Guernsey and Holstein records. Bulletin (University of Illinois (UrbanaChampaign campus). Agricultural 
Experiment Station); no. 288.

Gorewit, R. C. (1988). Lactation biology and methods of increasing efficiency. Designing Foods: Animal Product Options in the Marketplace. The National Academies Press, Washington DC, 208233.

Gradinaru, A. C., Creanga, S., and Solcan, G. (2015). Milk--a review on its synthesis, composition, and quality assurance in dairy industry. Human and Veterinary Medicine, 7(3).

Hadsell, D. L., Parlow, A. F., Torres, D., George, J., and Olea, W. (2008). Enhancement of maternal lactation performance during prolonged lactation in the mouse by mouse GH and long-R3IGF-I is linked to changes in mammary signaling and gene expression. Journal of Endocrinology, 198(1), 61-70.

Holcomb, C. S., Van Horn, H. H., Head, H. H., Hall, M. B., and Wilcox, C. J. (2001). Effects of prepartum dry matter intake and forage percentage on postpartum performance of lactating dairy cows. Journal of Dairy Science, 84(9), 20512058.

Husveth, F. 2011. Physiological and reproductional aspects of animal production. Debrecen University, University of West Hungary, Pannon University. p3.

Huzzey, J. M., Nydam, D. V., Grant, R. J., and Overton, T. R. (2011). Associations of prepartum plasma cortisol, haptoglobin, fecal cortisol metabolites, and nonesterified fatty acids with postpartum health status in Holstein dairy cows.Journal of dairy science, 94(12), 5878-5889.

Kimber, I., Cumberbatch, M., Dearman, R. J., Headon, D. R., Bhushan, M., and Griffiths, C. E. 2002. Lactoferrin: influences on Langerhans cells, epidermal cytokines, and cutaneous inflammation. Biochemistry and cell biology, 80(1), 103-107.

Knight, C. D., Koenig, K. M., Rode, L. M., Vandenberg, M. J., and Vazquez-Anon,
M. (2004). U.S. Patent No. 6,814,988.

Washington, DC: U.S. Patent and Trademark Office.

Legrand, D., Elass, E., Carpentier, M., and Mazurier, J. (2005). Lactoferrin. Cellular and Molecular Life Sciences, 62(22), 2549.

Lemosquet, S., Rigout, S., Bach, A., Rulquin, H., and Blum, J. W. (2004). Glucose metabolism in lactating cows in response to isoenergetic infusions of propionic acid or duodenal glucose. Journal of Dairy Science, 87(6), 1767-1777.

Lollivier, V., and Marnet, P. G. (2005). Galactopoietic effect of milking in lactating Holstein cows: Role of physiological doses of oxytocin. Livestock Production Science, 95(1-2), 131-142.

Lollivier, V., Guinard-Flament, J., OllivierBousquet, M., and Marnet, P. G. (2002). Oxytocin and milk removal: two important sources of variation in milk production and milk quality during and between milkings. Reproduction Nutrition Development, 42(2), 173-186.

McMahon, C. D., Radcliff, R. P., Lookingland, K. J., and Tucker, H. A. (2001). Neuroregulation of growth hormone secretion in domestic animals.Domestic animal endocrinology, 20(2), 65-87.

McManaman, J. L., and Neville, M. C. (2003).Mammary physiology and milk secretion.Advanced drug delivery reviews,55(5), 629-641.

Mostl, E., and Palme, R. (2002).Hormones as indicators of stress. Domestic animal endocrinology, 23(1-2), 67-74

Papich, M. G. (2015). Saunders Handbook of Veterinary Drugs-E-Book: Small and Large Animal. Elsevier Health Sciences.

Purup, S., Sejrsen, K., Foldager, J., and Akers, R. M. (1993).Effect of exogenous bovine growth hormone and ovariectomy on prepubertal mammary growth, serum hormones and acute in-vitro proliferative response of mammary explants from Holstein heifers. Journal of Endocrinology, 139(1), 19-26. 
Rigout, S., Hurtaud, C., Lemosquet, S., Bach, A., and Rulquin, H. (2003). Lactational effect of propionic acid and duodenal glucose in cows. Journal of Dairy Science, 86(1), 243-253.

Riley, L. G., Wynn, P. C., Williamson, P., and Sheehy, P. A. 2008. The role of native bovine $\alpha$-lactalbumin in bovine mammary epithelial cell apoptosis and casein expression. Journal of dairy research, 75(3), 319-325.

Robinson, G. W., McKnight, R. A., Smith, G. H., and Hennighausen, L. (1995). Mammary epithelial cells undergo secretory differentiation in cycling virgins but require pregnancy for the establishment of terminal differentiation. Development, 121(7), 2079-2090.

Silanikove, N., Shamay, A., Shinder, D., and Moran, A. (2000). Stress down regulates milk yield in cows by plasmin induced $\beta$ casein product that blocks $\mathrm{K}+$ channels on the apical membranes. Life Sciences, 67(18), 2201-2212.

Sjaastad, O. V., Hove, K., and Sand, O. (2010). Physiology of domestic animals. Scan. Vet. Press.

Stefanon, B., Colitti, M., Gabai, G., Knight, C. H., and Wilde, C. J. 2002. Mammary apoptosis and lactation persistency in dairy animals. Journal of Dairy Research., 69(1), 37-52.
Tomita, M., Wakabayashi, H., Shin, K., Yamauchi, K., Yaeshima, T., and Iwatsuki, K. (2009). Twenty-five years of research on bovine lactoferrin applications. Biochimie, 91(1), 52-57.

Tonner, E., Allan, G. J., and Flint, D. J. (2000).Hormonal control of plasmin and tissue-type plasminogen activator activity in rat milk during involution of the mammary gland. Journal of endocrinology, 167(2), 265-274.

Tonner, E., Allan, G. J., and Flint, D. J. (2000).Hormonal control of plasmin and tissue-type plasminogen activator activity in rat milk during involution of the mammary gland. Journal of endocrinology, 167(2), 265-274.

Zamiri, M. J., Qotbi, A., and Izadifard, J. (2001).Effect of daily oxytocin injection on milk yield and lactation length in sheep. Small Ruminant Research, 40(2), 179-185.

Zhao, K., Liu, H. Y., Zhou, M. M., Zhao, F. Q., and Liu, J. X. (2014). Insulin stimulates glucose uptake via a phosphatidylinositide 3-kinase-linked signaling pathway in bovine mammary epithelial cells. Journal of dairy science, 97(6), 3660-3665.

\section{How to cite this article:}

Mishra, S. M., A. K. Roy, Singh Mahendra and Gupta, I. D. 2020. Effect of Certain Plasma Hormones, Metabolites, Milk $\alpha$-lactalbumin and Lactoferrin on the Persistency of Lactation in Sahiwal Cattle. Int.J.Curr.Microbiol.App.Sci. 9(08): 2279-2290. doi: https://doi.org/10.20546/ijcmas.2020.908.261 